\title{
Suitability of Water Sources for Domestic and Irrigation Purpose around Corporate Dumpsite
}

\author{
Sidhardhan Susaiappan ${ }^{1 *}$, Adishkumar Somanathan ${ }^{2}$, Mannar Thippu Sulthan ${ }^{1}$ \\ ${ }^{1}$ Department of civil engineering, Government College of Engineering, Tirunelveli-627007, Tamilnadu, India \\ ${ }^{2}$ Department of Civil Engineering, VOC University College of Engineering, Anna University, \\ Thoothukudi-628008, Tamilnadu, India
}

Received: 4 August 2020

Accepted: 5 December 2020

\begin{abstract}
Water is an important resource for domestic, agriculture, and industrial purpose. The urban population requires a wide range of urban services including water supply, sewerage, and solid waste management. In most cities, the solid waste is dumped in open dumps without proper lining which affects the environmental media such as water and land. So the present study was focused on the impact of leachate on water quality. Water samples were collected from the Ramayanpatti dump site and the surrounding area. The water samples were tested for various physiochemical parameters and also predict the various effective irrigation indices such as Sodium Absorption Ratio, Residual Sodium Carbonate, Soluble Sodium Percent, Magnesium Absorption Ratio and Chloro-Alkaline Indices. Based on the Water Quality Index and irrigation indices most of the samples were not suitable for domestic as well as irrigation purposes. This indicates that the water is contaminated by leachate.
\end{abstract}

Keywords: water quality index, SAR, RSC, open dump, MAR

\section{Introduction}

Water is the most essential substance for the survival of life on earth. The fresh water resource available for usage is decreasing now a day due to various human activities. Groundwater is one of the most relied freshwater resources for domestic, agricultural and industrial purposes as it is available throughout the year and is polluted lesser than surface water [1, 2]. About $50 \%$ of the demand in municipal, domestic, and

*e-mail: sidhardhant@yahoo.co.in agricultural water supply is met using groundwater. In recent years much groundwater pollution have been noted because of increased usage due to rapid urbanization, industrialisation and population growth [3]. The engineered landfill disposal of solid waste protects the groundwater sources. However, the developing countries like India more than $90 \%$ of solid waste disposed in open dump in an unsatisfactory manner [4]. Open dump is one of the major polluting sources of ground water [5]. Municipal Solid Waste (MSW) contains combination of various organic and inorganic substances. Food waste, paper waste, coconut shells, husks and yard waste constitute a major portion of organic waste, and the inorganic wastes consists 


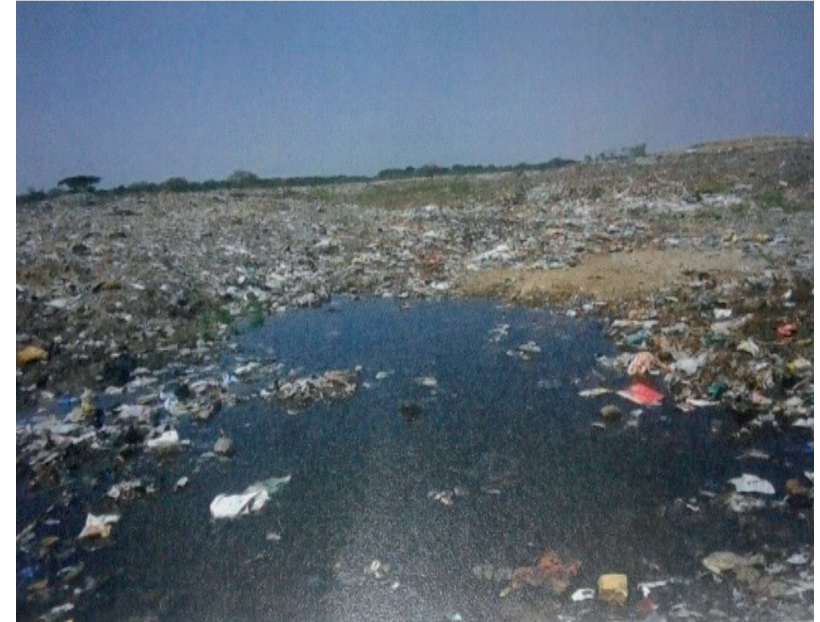

Fig. 1. An overview of Ramayanpatti dumpsite in Tirunelveli.

of mainly thin plastic food wraps, drinking water bottles, soft drink bottles, milk packaging cover, grocery bags and disposable cups [6]. Due to the waste disposal in open dump and infiltration from precipitation over waste generate landfill leachate which contaminates the water sources [7]. The pollutant from the waste materials of the landfill gets transferred to the percolating water there by forming strong leachate. This transfer of pollutants happens through various physical, chemical and biological processes [8]. The leachate contains lot of harmful compounds which pollute water sources and affect best usage of water. Hence it is essential to analyze the quality of water around dumpsite before usage.

\section{Materials and Methods}

\section{Study Area}

Tirunelveli municipality was upgraded into a corporation in the year 1994. It has got a population of about 474838 covering an area of $108.65 \mathrm{~km}^{2}$. It ranges between latitude $8^{\circ} 45^{\prime} 20^{\prime \prime}$ and longitude $77^{\circ} 40^{\prime} 29^{\prime \prime}$. The solid waste generated from Tirunelveli city was dumped in the Ramayanpatti municipal dumpsite (Fig. 1). The dumping site spread across 118 acres of land having an elevation of $54 \mathrm{~m}$. Tirunelveli Corporation disposes nearly of 10 tons of garbage every day in which the per capita waste is around $379 \mathrm{~g}$. The average rainfall is $879 \mathrm{~mm}$.

Geological formation of the study area consists of horn blended biotite gneissic overlying by weathered rock followed by thin soil. The general rock formation is striking in east-west direction and dipping towards south with an angle of $75^{\circ} \mathrm{S}$. It is found that limestone flanked by Kankar followed by quartzite on the northern side and in the southern side magnesium, limestone, calcareous quartzite and calcgneiss were found. The study area falls under pediment geomorphic unit with the absence of lineaments. In general the Pediments are hard rock terrains forming outcrops with or without soil cover.

Due to improper maintenance of the dumping site; the surrounding boreholes have been contaminated. The Ramayanpatti dumpsite was chosen as the study area to assess the degradation of groundwater quality in and around it. The study area includes residential zone, agricultural farm lands and fresh-water ponds.

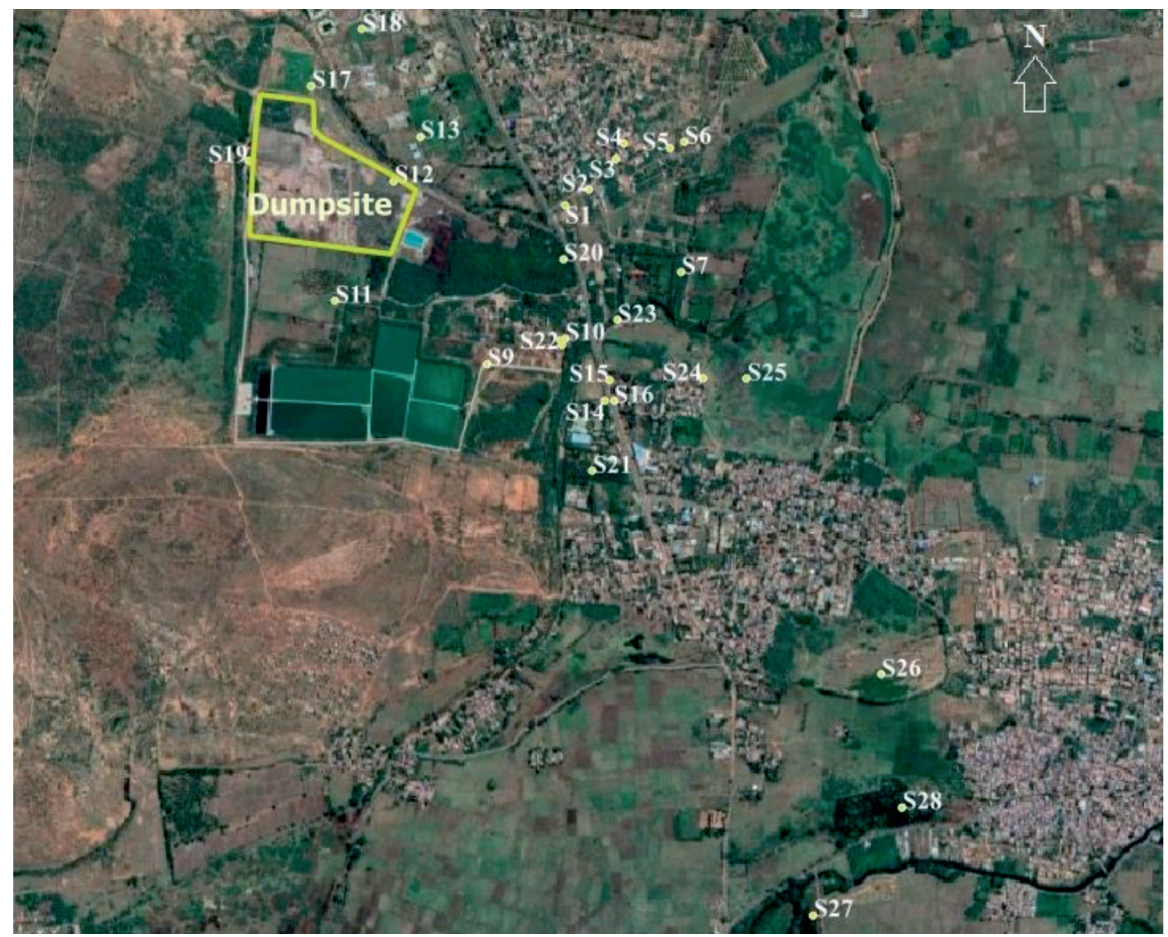

Fig. 2. Location of sampling sites in the study area. 


\section{Field Sampling}

Water samples were identified and collected from twenty two groundwater sampling sites and six surface water sampling sites (Fig. 2). The groundwater sampling sites includes bore wells, hand pumps and open wells. For quality analysis, water samples were collected in 5 litre plastic containers and prior to collection, as a part of quality control measures, all the containers were washed with non-ionic detergent and rinsed with de-ionised water. Before the final water sampling, the containers were labelled and transported to the laboratory.

\section{Analytical Techniques and Laboratory Analysis}

The adopted methods of analyses for the examination of parameters such as $\mathrm{pH}$, alkalinity, hardness, TDS, chloride, sulphate, calcium, magnesium, sodium and potassium were in accordance with IS 3025 standard recommendation. The impact on several parameter of water quality is characterised by single rating scale of WQI. It is a significant indicator for the assessment of groundwater. Weighted arithmetic method was used to arrive the Water Quality Index (WQI). Parameters such as $\mathrm{pH}$, alkalinity, hardness, chloride, sulphate and TDS were considered to find out WQI Value. WQI value represents the drinking water quality of the sample (Table 1).

Methods used for analysis of quality parameters for water samples:

PARAMETERS -

$\mathrm{pH}$

TDS

Alkalinity

Chloride

Total hardness -

Sulphate

Sodium

Potassium

Calcium

\section{METHOD}

$\mathrm{pH}$ Meter

TDS meter (TDS3TM)

Titration Method

Titration Method

Titration Method

Turbid metric method

Flame photometer

Flame photometer

Titration Method

\section{Irrigation Purpose}

Water quality is affected by the dissolution of minerals from the soil, leachate from open dumpsites

Table 1. Permissible Limits as Per IS and WHO Standards.

\begin{tabular}{|c|c|c|c|}
\hline Parameters & IS 10500:2012 & WHO & Weight \\
\hline $\mathrm{pH}$ & $6.5-8.5$ & $6.5-8.5$ & 4 \\
\hline $\mathrm{TDS}$ & 500 & 1,000 & 4 \\
\hline $\mathrm{TH}$ & 300 & 100 & 3 \\
\hline $\mathrm{Cl}$ & 250 & 250 & 3 \\
\hline Sulphate & 200 & 250 & 4 \\
\hline Alkalinity & 0.3 & 0.1 & 2 \\
\hline
\end{tabular}

etc. Hence it becomes essential to assess its quality before using it for irrigation. The yield of the crop and the texture of soil are mainly influenced by the presence of excess chemical components and salt content in water [9]. The parameters such as sodium adsorption ratio (SAR), residual sodium carbonate (RSC), soluble sodium percentage $(\% \mathrm{Na})$, Kelly's ratio (KR), and magnesium adsorption ratio (MAR) were determined to find out the irrigation water quality.

Sodium Adsorption Ratio: $\mathrm{SAR}=\frac{\mathrm{Na}^{+}}{\sqrt{\left(\mathrm{Ca}^{2+}+\mathrm{Mg}^{2+}\right) / 2}}$

Residual Sodium Carbonate:

$$
\begin{aligned}
& \mathrm{RSC}=\left(\mathrm{HCO}_{3}^{-}+\mathrm{CO}_{3}^{2-}\right)-\left(\mathrm{Ca}^{2+}+\mathrm{Mg}^{2+}\right) \\
& \text { Permeability Index: } \mathrm{PI}=\frac{\mathrm{Na}^{+}+\sqrt{\mathrm{HCO}_{3}^{-}}}{\mathrm{Na}^{+}+\mathrm{Mg}^{2+}+\mathrm{Ca}^{2+}}
\end{aligned}
$$

Kelly Ratio: $\mathrm{KR}=\frac{\mathrm{Na}^{+}}{\left(\mathrm{Ca}^{2+}+\mathrm{Mg}^{2+}\right)}$

Soluble Sodium Percentage:

$$
\mathrm{SSP}=\frac{\mathrm{Na}^{+}+\mathrm{K}^{+}}{\mathrm{Ca}^{2+}+\mathrm{Mg}^{2+}+\mathrm{Na}^{+}+\mathrm{K}^{+}} \times 100
$$

Magnesium Adsorption Ratio:

$$
\mathrm{MAR}=\frac{\mathrm{Mg}^{2+}}{\left(\mathrm{Ca}^{2+}+\mathrm{Mg}^{2+}\right)} \times 100
$$

\section{Results and Discussion}

Domestic Water Suitability

$$
p H
$$

$\mathrm{pH}$ is the measure of hydrogen ion concentration in water. It helps in finding the nature of water whether acidic or alkaline. In drinking water quality, $\mathrm{pH}$ is not of a health concern because, most of the groundwater sample has value varied from 6.4 to 8.2. However, high $\mathrm{pH}$ values (10-12.5) may cause gastrointestinal irritation, similarly very low $\mathrm{pH}$ can cause irritation to the skin, eyes and mucous membrane [10] The highest $\mathrm{pH}$ value of 8.2 was found at the sampling site S21 while the lowest $\mathrm{pH}$ value of 6.4 was found at the sampling sites S4 and S20. Except for the sampling site S4 and S20, all other sampling sites had their $\mathrm{pH}$ values within permissible limits of 6.5-8.5 as per IS-10500:2012 and WHO standards and are suitable for drinking [11, 12].

\section{Alkalinity}

Alkalinity is the measure of the ability of substances in water to neutralize acids [13]. Majorly the calcareous 
and limestone formation impart the higher alkalinity [14]. The alkalinity value was found to be maximum at the site $\mathrm{S} 23$ with a value of $625 \mathrm{mg} / \mathrm{L}$ as $\mathrm{CaCO}_{3}$ and the minimum value of alkalinity was found to be $215 \mathrm{mg} / \mathrm{L}$ as $\mathrm{CaCO}_{3}$ at the sampling site S5. Almost all the samples shad their alkalinity values within maximum permissible limit of $600 \mathrm{mg} / \mathrm{L}$.

\section{Total Hardness}

Total Hardness may be defined as the total concentration of magnesium and calcium in $\mathrm{mg} / \mathrm{L}$ equivalent of $\mathrm{CaCO}_{3}$. Hardness in water prevents it from forming lather when added with soap. Though hardness doesn't have adverse effects below permissible value but when hardness rises above $300 \mathrm{mg} / \mathrm{L}$, it may cause kidney related ailments [15] The highest value of total hardness was found to be $2160 \mathrm{mg} / \mathrm{L}$ as $\mathrm{CaCO}_{3}$ at the sampling site $\mathrm{S} 3$ while the lowest value of total hardness was found as $600 \mathrm{mg} / \mathrm{L}$ as $\mathrm{CaCO}_{3}$ in $\mathrm{S} 25$ and S27 site.

\section{Chloride}

All natural waters contain chloride but comparatively of smaller amount, however, it also can be derived from

Table 2. Physicochemical characteristics of water from sampling sites.

\begin{tabular}{|c|c|c|c|c|c|c|c|c|c|c|}
\hline $\begin{array}{l}\text { Sampling } \\
\text { site }\end{array}$ & $\mathrm{pH}$ & $\begin{array}{l}\text { Total Alkalinity in } \\
\mathrm{mg} / \mathrm{L} \text { as } \mathrm{CaCO}_{3}\end{array}$ & $\begin{array}{l}\text { Total Hardness as } \\
\mathrm{mg} / \mathrm{L} \text { as } \mathrm{CaCO}_{3}\end{array}$ & $\begin{array}{l}\mathrm{Cl}^{-} \text {in } \\
\mathrm{mg} / \mathrm{L}\end{array}$ & $\begin{array}{c}\mathrm{Ca}^{2+} \text { in } \\
\mathrm{mg} / \mathrm{L}\end{array}$ & $\begin{array}{c}\mathrm{Mg}^{2+} \text { in } \\
\mathrm{mg} / \mathrm{L}\end{array}$ & $\begin{array}{c}\mathrm{SO}_{4}^{2-} \text { in } \\
\mathrm{mg} / \mathrm{L}\end{array}$ & $\begin{array}{l}\mathrm{Na}^{+} \text {in } \\
\mathrm{mg} / \mathrm{L}\end{array}$ & $\begin{array}{l}\mathrm{K}^{+} \text {in } \\
\mathrm{mg} / \mathrm{L}\end{array}$ & $\begin{array}{c}\text { TDS in } \\
\mathrm{mg} / \mathrm{L}\end{array}$ \\
\hline $\mathrm{S} 1$ & 7.3 & 475.0 & 1880.0 & 2149.0 & 416.0 & 201.6 & 417.0 & 420.0 & 9.5 & 2440.0 \\
\hline S2 & 7.4 & 415.0 & 1600.0 & 1949.0 & 320.0 & 192.0 & 388.0 & 487.0 & 9.2 & 2500.0 \\
\hline S3 & 6.6 & 255.0 & 2160.0 & 2698.0 & 512.0 & 211.2 & 528.0 & 537.0 & 12.8 & 3070.0 \\
\hline S4 & 6.4 & 300.0 & 1240.0 & 1499.0 & 288.0 & 124.8 & 198.0 & 316.0 & 8.7 & 1650.0 \\
\hline S5 & 7.9 & 215.0 & 1200.0 & 1299.0 & 224.0 & 153.6 & 123.0 & 278.0 & 12.6 & 1670.0 \\
\hline S6 & 6.9 & 500.0 & 960.0 & 699.0 & 176.0 & 124.8 & 214.0 & 298.0 & 6.5 & 1190.0 \\
\hline S7 & 7.2 & 475.0 & 1120.0 & 949.0 & 332.0 & 69.6 & 260.0 & 250.0 & 6.2 & 1300.0 \\
\hline S8 & 7.6 & 465.0 & 1400.0 & 1099.0 & 224.0 & 201.6 & 186.0 & 286.0 & 8.9 & 1510.0 \\
\hline S9 & 6.8 & 535.0 & 1120.0 & 1099.0 & 304.0 & 86.4 & 226.0 & 304.0 & 2.9 & 1540.0 \\
\hline S10 & 7.1 & 375.0 & 1280.0 & 1199.0 & 240.0 & 163.2 & 32.0 & 427.0 & 11.3 & 1740.0 \\
\hline S11 & 6.8 & 435.0 & 720.0 & 699.0 & 80.0 & 124.8 & 40.0 & 214.0 & 5.9 & 852.0 \\
\hline $\mathrm{S} 12$ & 6.6 & 325.0 & 1680.0 & 1999.0 & 480.0 & 115.2 & 295.0 & 407.0 & 11.7 & 2550.0 \\
\hline S13 & 7.5 & 335.0 & 680.0 & 3048.0 & 128.0 & 86.4 & 608.0 & 549.0 & 13.5 & 3280.0 \\
\hline S14 & 6.6 & 565.0 & 760.0 & 599.0 & 112.0 & 115.2 & 60.0 & 213.0 & 8.8 & 910.0 \\
\hline S15 & 8.0 & 540.0 & 680.0 & 649.0 & 96.0 & 105.6 & 82.0 & 260.0 & 16.1 & 982.0 \\
\hline S16 & 7.4 & 560.0 & 720.0 & 699.0 & 176.0 & 67.2 & 98.0 & 301.0 & 9.6 & 1070.0 \\
\hline S17 & 7.5 & 485.0 & 690.0 & 449.0 & 128.0 & 88.8 & 82.0 & 38.0 & 77.8 & 623.0 \\
\hline S18 & 7.5 & 495.0 & 705.0 & 349.0 & 128.0 & 92.4 & 90.0 & 38.0 & 77.5 & 644.0 \\
\hline S19 & 6.7 & 310.0 & 800.0 & 299.0 & 192.0 & 76.8 & 96.0 & 55.0 & 12.2 & 485.0 \\
\hline S20 & 6.4 & 490.0 & 1000.0 & 849.0 & 256.0 & 86.4 & 251.0 & 263.0 & 13.8 & 1150.0 \\
\hline S21 & 8.2 & 400.0 & 900.0 & 280.0 & 212.0 & 88.8 & 138.0 & 133.0 & 33.2 & 583.0 \\
\hline S22 & 7.4 & 560.0 & 1320.0 & 1380.0 & 224.0 & 182.4 & 127.0 & 294.0 & 17.0 & 1720.0 \\
\hline S23 & 6.8 & 625.0 & 820.0 & 500.0 & 192.0 & 81.6 & 150.0 & 134.0 & 33.2 & 603.0 \\
\hline S24 & 6.5 & 500.0 & 1000.0 & 350.0 & 268.0 & 79.2 & 104.0 & 27.0 & 5.6 & 615.0 \\
\hline S25 & 7.3 & 500.0 & 600.0 & 350.0 & 128.0 & 67.2 & 50.0 & 15.0 & 4.8 & 595 \\
\hline S26 & 7.1 & 300.0 & 900.0 & 300.0 & 204.0 & 93.6 & 82.0 & 11.0 & 1.9 & 510 \\
\hline S27 & 6.8 & 400.0 & 600.0 & 250.0 & 136.0 & 62.4 & 78.0 & 25.0 & 8.2 & 565 \\
\hline S28 & 7.8 & 520.0 & 860.0 & 400.0 & 192.0 & 91.2 & 90.0 & 51.0 & 6.1 & 580.0 \\
\hline
\end{tabular}


human activities [16]. The highest value of chloride was found as $3048 \mathrm{mg} / \mathrm{L}$ at the sampling site S13 while the lowest value was found as $250 \mathrm{mg} / \mathrm{L}$ at the sampling site S25 which is a surface water source, located in the west direction of dumping site. The higher concentration of chloride shows the contamination of water by leachate from landfill [17].

\section{Calcium}

Calcium is one of the most common elements found in water and it contributes to hardness [18]. The maximum permissible limit for calcium for drinking purposes according to Indian Standards is $200 \mathrm{mg} / \mathrm{L}$.
The highest and lowest values of calcium were found as $512 \mathrm{mg} / \mathrm{L}$ and $80 \mathrm{mg} / \mathrm{L}$ at the sampling sites $\mathrm{S} 3$ and S11 respectively. Nearly $54 \%$ of the samples exceeded permissible limits and are unsuitable for drinking.

\section{Magnesium}

Magnesium is an important drinking water quality parameter as it imparts hardness to water. Excess Magnesium concentration affects the quality of soil resulting in poor crop yield [19]. The maximum and minimum values of magnesium were found as $211.2 \mathrm{mg} / \mathrm{L}$ and $62.4 \mathrm{mg} / \mathrm{L}$ at the sampling sites S3 and S25 respectively. These high values of magnesium present

Table 3. Water Quality Index of sampling sites.

\begin{tabular}{|c|c|c|c|c|c|c|}
\hline S. No & LOCATION & Latitude & Longitude & Elevation & WQI & Water Quality \\
\hline $\mathrm{S} 1$ & 4/627, Balaji Nagar & 8.76288 & 77.68608 & 47.5 & 381.65 & Water unsuitable for drinking \\
\hline $\mathrm{S} 2$ & 4/591, Balaji Nagar & 8.76332 & 77.6868 & 48 & 354.06 & Water unsuitable for drinking \\
\hline $\mathrm{S} 3$ & 4/573, Sivaji Nagar & 8.76422 & 77.6876 & 48 & 463.67 & Water unsuitable for drinking \\
\hline $\mathrm{S} 4$ & Plot no:114, Sivaji Nagar & 8.76467 & 77.6878 & 49 & 272.78 & Very poor water \\
\hline S5 & Sivaji Nagar & 8.76454 & 77.68916 & 49.5 & 237.33 & Very poor water \\
\hline S6 & Sivaji Nagar & 8.76472 & 77.68959 & 49.5 & 183.66 & Very water \\
\hline S7 & UGS Nagar & 8.7609 & 77.6895 & 51.5 & 212.16 & Very poor water \\
\hline S8 & Annai Velankani Nagar & 8.75874 & 77.68598 & 51 & 242.47 & Very poor water \\
\hline S9 & Vinayagar Temple, Annai Velankani Nagar & 8.7582 & 77.6838 & 51.5 & 236.37 & Very poor water \\
\hline S10 & Annai Velankani Nagar & 8.75895 & 77.68609 & 51.5 & 228.18 & Very poor water \\
\hline S11 & Sakthi Thoppu & 8.76005 & 77.67933 & 54 & 144.97 & Poor water \\
\hline $\mathrm{S} 12$ & Dump site & 8.763575 & 77.68107 & 54 & 361.79 & Water unsuitable for drinking \\
\hline $\mathrm{S} 13$ & Veterinary college field & 8.764877 & 77.68184 & 52.5 & 420.14 & Water unsuitable for drinking \\
\hline S14 & 10/375, Ramayanpatti & 8.757099 & 77.68728 & 48 & 159.39 & Poor water \\
\hline S15 & 5B, Ramayanpatti & 8.757731 & 77.68739 & 49 & 159.11 & Poor water \\
\hline S16 & 5/65, Ramayanpatti & 8.757118 & 77.68752 & 49 & 161.91 & Poor water \\
\hline S17 & Corporation park & 8.766357 & 77.67865 & 54.5 & 123.84 & Poor water \\
\hline S18 & Veterinary college & 8.768016 & 77.68013 & 53 & 120.57 & Poor water \\
\hline S19 & Sasthakovil & 8.764163 & 77.6768 & 55 & 112.52 & Poor water \\
\hline S20 & Annai Velankani Nagar Field & 8.761278 & 77.68604 & 51.5 & 215.52 & Very poor water \\
\hline $\mathrm{S} 21$ & Ramayanpatti farm land & 8.755056 & 77.68689 & 49.5 & 132.16 & Poor water \\
\hline S22 & 10/200, Annai Velankani Nagar & 8.758907 & 77.68594 & 50.5 & 261.09 & Very poor water \\
\hline S23 & Kodagan Canal & 8.759486 & 77.68762 & 51 & 146.37 & Poor water \\
\hline S24 & Thenirkulam & 8.75777 & 77.69013 & 50 & 148.92 & Poor water \\
\hline S25 & Megamudaiyarkulam & 8.757769 & 77.69143 & 54 & 106.33 & Poor water \\
\hline $\mathrm{S} 26$ & Illanthaikulam & 8.74909 & 77.69537 & 51 & 105.70 & Poor water \\
\hline $\mathrm{S} 27$ & Nainarkulam & 8.742028 & 77.69338 & 46 & 100.58 & Poor water \\
\hline S28 & Seeniyappankulam & 8.745188 & 77.69599 & 49 & 134.07 & Poor water \\
\hline
\end{tabular}


in the groundwater samples are due to the infiltration of toxic material from the open dumpsite [20].

\section{Sulphate}

It is a major mineral present in water. According to Indian standards, the acceptable limit for sulphate in drinking water is $200 \mathrm{mg} / \mathrm{L}$ and the maximum permissible limit is $400 \mathrm{mg} / \mathrm{L}$. Excess sulphate in water causes laxative effect and irritation of gastro- intestinal tract [21]. In our study area, the highest value of Sulphate was found as $608 \mathrm{mg} / \mathrm{L}$ at the sampling site S13 while the minimum value of Sulphate was found to be $32 \mathrm{mg} / \mathrm{L}$ at the sampling site S10.

\section{Sodium}

Generally sodium is present in water due to the dissolution of the weathered rock materials However higher concentrations are attributed due to the pollution from industrial wastes which is disposed in dumpsites [22]. The concentration of sodium was found to be highest, that is $549 \mathrm{mg} / \mathrm{L}$ at the sampling site S13 while the lowest concentration of $11 \mathrm{mg} / \mathrm{L}$ was observed in the sampling site S26.

\section{Potassium}

The maximum potassium concentration was found as $77.8 \mathrm{mg} / \mathrm{L}$ at the sampling site $\mathrm{S} 17$ while the minimum concentration was found to be $1.9 \mathrm{mg} / \mathrm{L}$ at the sampling site S26. The higher potassium ion concentration in the water samples may be from the leachate of the nearby dumpsite [23].

\section{$T D S$}

The highest concentration of TDS was found to be $3280 \mathrm{mg} / \mathrm{L}$ at the sampling site S13 while the minimum TDS concentration was found as $485 \mathrm{mg} / \mathrm{L}$ at the sampling site S19. (Table 2). Of the 28 sampling stations, 13 sampling sites have their TDS values above $1000 \mathrm{mg} / \mathrm{L}$. This shows that water in such sampling sites are brackish and are unsuitable for drinking [24].

\section{$W Q I$}

The WQI has been used to identify the quality of water for drinking purposes [25] Maximum WQI value was found as 463.67 in sampling site S3 and minimum WQI value was 100.58 in sampling site S27. The WQI values indicate that water samples around dumpsites were not suitable for drinking purposes. Mostly the groundwater quality is alone influenced by the leachate from dumpsite while the surface water sources were least affected (Table 3 and Table 4).

The ground water level variation around the study area was almost similar to reduced level variation
Table 4. Water quality classification based on WQI value.

\begin{tabular}{|c|c|c|c|}
\hline $\begin{array}{c}\text { WQI } \\
\text { value }\end{array}$ & Water quality & $\begin{array}{c}\text { No } \\
\text { of Samples }\end{array}$ & Percentage \\
\hline$<50$ & Excellent & 0 & 0 \\
\hline $50-100$ & Good water & 0 & 0 \\
\hline $100-200$ & Poor water & 15 & 53.57 \\
\hline $200-300$ & Very poor water & 8 & 28.57 \\
\hline$>300$ & $\begin{array}{c}\text { Water unsuitable for } \\
\text { drinking }\end{array}$ & 5 & 17.86 \\
\hline
\end{tabular}

of the ground surface. The top soil was found up to a depth of $1 \mathrm{~m}$ below ground level, weathered/partly weathered rock layer was present next to the top soil. The groundwater table was identified within this weathered/partly weathered rock layer. In most of the sampling sites the water table was found to be present at a depth of about $5.5 \mathrm{~m}$ to $7.5 \mathrm{~m}$. The reduced level of dumpsite was found as $54 \mathrm{~m}$, while the most polluted sampling site S1, S2 and S3 with the WQI value of 381.65 , 354.06 and 463.67 respectively and were at an elevation of around $48 \mathrm{~m}$. This shows that the groundwater flows in Eastern direction from dumpsite towards Sivaji nagar around which the sampling sites S1, S2 and S3 were situated (Fig. 3). The groundwater flow happens through the cracks in the rock layer along the slope of the ground surface. The sampling stations S1, S2, S3, S4, S5, S12 and S13 were highly polluted because of their location along ground water flow direction. Moreover the sampling stations S1, S2, S3, S4 and S5 were located in the bell mouth region of watershed. The least polluted groundwater sampling site was S19 with the WQI value of 112.52 which has an elevation of $55 \mathrm{~m}$ and was located in the upstream side of groundwater flow from dumpsite. The sampling sites S23, S24, S25, S26, S27 and S28 were surface water bodies which were situated far away from the dumpsite and hence they are less polluted.

\section{Irrigation Suitability}

The irrigation suitability in the water sampling sites was based on the presence of soluble salts and mineral constituents in the water samples. Higher concentration of salts and the insufficient or excess concentration of minerals can affect the growth of plants and soil [26]. In this study, irrigation suitability was evaluated based on the indices such as SAR, RSC, PI, SSP, MAR and KR. Table 5 shows the irrigation water quality indices for the classification of water samples.

\section{$S A R$}

Sodium Adsorption Ratio (SAR) is a useful index for predicting the tendency of a salt solution which can produce excessive exchangeable sodium in the soil [27]. Groundwater samples with SAR less than 


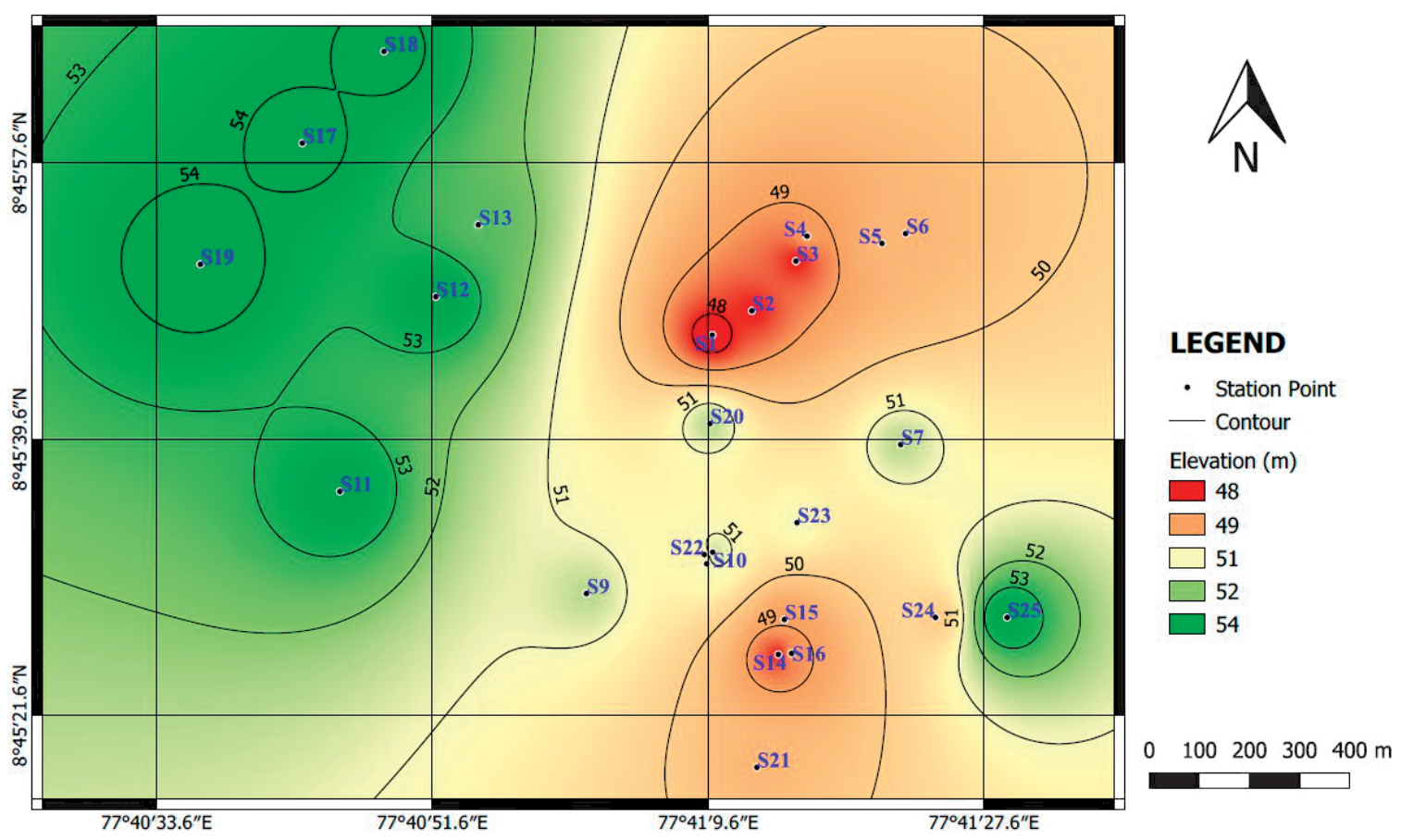

Fig. 3. Spatial variation of elevation around dumpsite.

Table 5. Irrigation Water Quality Indices for Classification.

\begin{tabular}{|c|c|c|c|}
\hline Irrigation Parameter & Type of water & No. of samples & Percentage of Sample \\
\hline \multicolumn{4}{|l|}{ S.A.R } \\
\hline$<10$ & Excellent & 28 & 100 \\
\hline 10 to 18 & Good & 0 & 0 \\
\hline 18 to 26 & Permissible & 0 & 0 \\
\hline$>26$ & Unsuitable & 0 & 0 \\
\hline R.S.C & Type of water & No. of samples & Percentage of Sample \\
\hline$<1.25$ & Good & 28 & 100 \\
\hline 1.25 to 2.5 & Marginal & 0 & 0 \\
\hline$>2.5$ & Unsuitable & 0 & 0 \\
\hline P.I & Type of water & No. of samples & Percentage of Sample \\
\hline$>75 \%$ & Good & 0 & 0 \\
\hline $75-25 \%$ & Permissible & 26 & 92.86 \\
\hline$<25 \%$ & Unsuitable & 2 & 7.14 \\
\hline S.S.P & Type of water & No. of samples & Percentage of Sample \\
\hline$<60$ & Suitable & 28 & 100 \\
\hline$>60$ & Unsuitable & 0 & 0 \\
\hline M.A.R & Type of water & No. of samples & Percentage of Sample \\
\hline$<50$ & Suitable & 17 & 60.71 \\
\hline$>50$ & Unsuitable & 11 & 39.29 \\
\hline K.R & Type of water & No. of samples & Percentage of Sample \\
\hline$<1$ & Suitable & 27 & 96.43 \\
\hline$>1$ & Unsuitable & 1 & 3.57 \\
\hline
\end{tabular}


10 are considered excellent and are highly suitable for irrigation [28]. Those samples with SAR greater than 26 are unsuitable for irrigation. In our study area, all the samples had SAR below 10 and are of excellent quality.

\section{$R S C$}

Residual Sodium Carbonate (RSC) is the amount of excess or surplus quantity of carbonate and bicarbonates compared to the alkaline Earth. It represents the terrible effects of carbonate and bicarbonate in water quality [29]. The higher the value of RSC, the higher is the potential for sodium hazard. This is because, at higher RSC values the calcium and magnesium ions get easily precipitated from the water, thus increasing the share of sodium in water and soil [30]. Continuous use of water with high RSC values affects the leaves of the plants and decreases the crop yield. Water with RSC values greater than 2.5 are unsuitable for irrigation, while that with RSC values less than 1.25 are good and suitable for irrigation. In our study area, all the 28 samples had RSC values less than 1.25 and are suitable for irrigation.

\section{$P I$}

The use of irrigation water for a long time has a great effect in the permeability of soil. This is influenced by the bicarbonate content, dissolved salts and sodium content. [31]. Based on PI, the water samples can be categorized as good, when it has value greater than $75 \%$ and the water is termed as permissible when it has its permeability index between $75 \%$ and $25 \%$. Water is considered to be unsuitable for irrigation purpose, when PI value is less than $25 \%$. In our study area, except the sampling sites S24 and S26, water from all other sampling sites were permissible for irrigation.

\section{SSP}

Soluble Sodium Percentage (SSP) is broadly used to determine the suitability of water for irrigation [32]. SSP helps in evaluating sodium hazard. High SSP results in the release of $\mathrm{Ca}^{2+}$ and $\mathrm{Mg}^{2+}$ ions to the soil due to the absorption of sodium by clay particles. Combination of sodium with carbonates results in alkaline soil whereas its combination with chloride results in saline soil which is unsuitable for agriculture [33]. Water samples with SSP less than 60 are suitable for irrigation purpose and that with SSP greater than 60 are unsuitable. In our study area, all the samples had SSP values less than 60 and are suitable for irrigation.

\section{$M A R$}

Magnesium Absorption Ratio (MAR) defined in equation (6) is an indicator of magnesium hazard, which occur when magnesium remains in equilibrium with water. In MAR index both calcium and magnesium are taken into consideration as they both together exist in equilibrium with water [34]. Samples with MAR below $50 \%$ are suitable for irrigation purpose while that above $50 \%$ is unsuitable. Of the 28 samples, 17 samples were less than $50 \%$ of MAR and were suitable for the irrigation purpose, while 11 samples were found to be unsuitable.

$K R$

Kelly Ratio is the level of sodium measured against magnesium and calcium [35]. The water sample is considered unsuitable and the concentration of sodium is considered excess when $\mathrm{KR}>1$. The water is suitable for irrigation purposes when $\mathrm{KR}<1$ [36]. In the study area, Kelly Ratio showed that except sample S13, all other samples were suitable for irrigation.

\section{Conclusions}

From the present study it was found that in and around Ramayanpatti dumpsite most of the sampling sites have TDS, alkalinity, chloride, sulphate and TH values exceed permissible limits making water of those particular areas unsuitable for drinking purpose. While the presence of these pollutants is not very much harmful to human health, but this study does point out that there are strong possibilities that other lethal contaminant like metal ions may have reached these water sources along with the pollutants studied [37]. The WQI value for groundwater samples varied from 112.52 to 463.67 which represent groundwater around dumpsite were in the range of poor quality water to water unsuitable for drinking purposes. WQI value for samples from surface water sources ranges from 100.58 to 146.37 which shows the surface water sources were least affected by open dump than groundwater. The irrigation indices shows that almost all the samples were suitable for irrigation purpose. Hence, it can be used for irrigation without any prior treatment. It can also be identified that the flow of leachate depends on the natural topography of the land area. The presence of this open dumpsite possesses huge environment threats to the water sources, proper measures are required to avoid contamination of water sources due to open dump. To decrease the contamination of surface and groundwater sources the farmers are interested to use biopesticides and biofertilizers. A long- term and shortterm management action plan should be framed for the efficient use of water resources.

\section{Acknowledgements}

The authors are thankful to the Principal and the Head of the Department of Civil Engineering, Government College of Engineering Tirunelveli for Laboratory facilities. 


\section{Conflict of Interest}

The authors declare no conflict of interest.

\section{References}

1. MAJKIC-DURSUN B., OROS I., OPARUSIC I., PETKOVIC A. Assessing groundwater quality for multiuse and geochemical evolution in the South Banat area of Serbia, Pannonia Basin. Polish Journal of Environmental Studies, 28 (5), 3269, 2019.

2. SARANYA A., SASHIKKUMAR M.C. Hydrochemical analysis of groundwater quality in Virudhunagar District, Tamil Nadu, India. Indian Journal of Ecology, 46 (1), 39, 2019.

3. KHAN R., JHARIYA D.C. Groundwater quality assessment for drinking purpose in Raipur City, Chhattisgarh using water quality index and geographic information system. Journal of the geological society of India, 90 (1), 69, 2017.

4. SACHIN MISHRA, DHANESH TIWARY, ANURAG OHRI, ASHWANI KUMAR A. Assessment of groundwater quality using WQI and GIS near the Karsara municipal landfill site, Varanasi, India. Arabian Journal of Geosciences, 11, 252, 2018.

5. FATTA D., PAPADOPOULOS A., LOIZIDIU M. A study on the landfill leachate and its impacts on the groundwater quality of the greater area. Environmental Geochemistry and Health, 21 (2), 171, 1999.

6. ANJU ELIZBATH PETER., SHIVA NAGENDRA SM, INDUMATHI MN. Environmental burden by an open dumpsite in urban India. Waste Management, 85, 151, 2019.

7. MOR S., RAVINDRA K., DAHIYA R.P., CHANDRA A. Leachate characterization and assessment of groundwater pollution near municipal solid waste landfill site. Environmental Monitoring and Assessment, 118, 435, 2006.

8. CHRISTENSEN T.H., KJELDSEN P., BJERG P.L., JENSEN D.L., CHRISTENSEN B.J., BAUN A., ALBRECHTSEN H., HERON G. Biogeochemistry of landfill leachate plumes. Applied Geochemistry, 16, 659, 2001.

9. NAGESWARA RAO P.V., APPA RAO S., SUBBA RAO N. Suitability of groundwater quality for drinking, irrigation and industrial purposes in the western delta region of the River Godavari, Andra Pradesh. Journal of Geological Society of India, 86 (2), 181, 2015.

10. AKHTAR M.M., TANG Z., MOHAMADI B. Contamination potential assessment of potable groundwater in Lahore, Pakistan. Polish Journal of Environmental Studies, 23 (6), 1905, 2014.

11. BUREAU OF INDIAN STANDARDS (BIS) 10500. Indian standard drinking water- specification. First revision 1991.

12. WORLD HEALTH ORGANIZATION (WHO). Guidelines for drinking water quality, $2^{\text {nd }}$ edn., $1: 188.1993$.

13. GORDON T., AMANGABARA, ENYINAYA, EJENMA. Groundwater quality assessment of Yenagoa and Environs Bayelsa State, Nigeria between 2010 and 2011. Resources and Environment, 2 (2), 20, 2012.

14. SIDDIQUI A., NASEEM S., JALIL T. Groundwater quality assessment in and around Kalu Khuhar, super highway, Sindh, Pakistan. Journal of Applied Sciences, $\mathbf{5}$ (7), 1260, 2005.
15. THAYALNAYAKI D., JAYANTHI R. Groundwater quality mapping of an open municipal solid waste landfill site. International Journal of Engineering and Advanced Technology (IJEAT), 9 (2), 1323, 2019.

16. IBRAHIM A.K., GADAM A.U., USMAN A., UMAR A.H. Suitability assessment of groundwater for drinking and irrigation use. IOSR Journal of Agriculture and Veterinary Science, 8 (4), 25, 2015.

17. SOUJANYA KAMBLE B., PRAVEEN RAJ SAXENA. Environmental impact of municipal dumpsite leachate on groundwater quality in Jawaharnagar, Rangareddy, Telangana, India. Applied Water Science, 7 (6), 3333, 2017.

18. IBRAHIM A.K., GADAM A.U., USMAN A., UMAR A.H. Suitability assessment of groundwater for drinking and irrigation use. Journal of Agriculture and Veterinary Science, 8 (4), 25, 2015.

19. VENKATESAN G., SWAMINATHAN G., NAGARAJAN R. Study on groundwater quality in and around solid waste landfill site at Tiruchirappalli, Tamil Nadu, India. International Journal of Environmental Engineering, 5 (2), 179, 2013.

20. OLAGUNJU E., BADMUS O., OGUNLANA F., BABALOLA M. Environmental impact assessment of waste dumpsite using integrated geochemical and physicochemical approach: a case study of Ilokun waste dumpsite, Ado-Ekiti, Southern Nigeria. Civil Engineering Research Journal, 4 (2), 34, 2018.

21. AL-TABBAL J., AL-ZBOO K. Suitability assessment of groundwater for irrigation and drinking purpose in the Northern Region of Jordan. Journal of Environmental Science and Technology, 5 (5),274, 2012.

22. SHAH S.M., MISTRY N.J. Evaluation of groundwater quality and its suitability for an agriculture use in, District Vadodara, Gujarat, India Research Journal of Engineering Sciences, 2 (11), 1, 2013.

23. SUGIRTHARAN M., RAJENDRAN M. Ground water quality near municipal solid waste dumping site at Thirupperumthurai, Batticaloa. Journal of Agricultural Sciences, 10 (1), 21, 2015.

24. RAO N.S., RAO P.S., REDDY G.V., NAGAMANI M., VIDYASAGAR G., SATYANARAYANA N.L.V.V. Chemical characteristics of groundwater and assessment of groundwater quality in Varaha River Basin, Visakhapatnam District, Andhra Pradesh, India, Environ. Monit. Assess., 184 (8), 5189, 2012.

25. ASADI E., ISAZADEH M., SAMADIANFARD S., RAMLI M.F., MOSAVI A., NABIPOUR N., SHAMSHIRBAND S., HAJNAL E., CHAU K. W. Groundwater quality assessment for sustainable drinking and irrigation. Sustainability, 12 (1), 177, 2020.

26. SHAHAB A., SHIHUA Q., RASHID A., HASAN F.U., SOHAIL M.T. Evaluation of water quality for drinking and agricultural suitability in the Lower Indus Plain in Sindh Province, Pakistan. Polish Journal of Environmental Studies, 25 (6), 2563, 2016.

27. ZAMAN M., SHAHID S.A., HENG L. Guideline for salinity assessment, mitigation and adaptation using nuclear and related techniques. Springer International Publishing, 113-131, 2018.

28. SARHAT A.R. Assessment of groundwater quality and its suitability for agricultural uses in Kifri. Journal of Garmian University, 4, 290, 2017.

29. KSHITINDRA K.S., GEETA TEWARI., SURESH KUMAR. Evaluation of groundwater quality for suitability of irrigation purposes: a case study in the Udham Singh Nagar, Uttarakhand, Journal of Chemistry, 2020, 1, 2020. 
30. GUPTA S., KUMAR., OJHA C.K., SINGH G. Assessment of water quality index for the groundwater in Tumkur Taluk, Karnataka State, India. Journal of Environmental Science and Engineering, 46 (1), 74, 2004.

31. BHAT.M., WANI S., SINGH V., SAHOO J., TOMAR D., PRAKASH R. An overview of the assessment of groundwater quality for irrigation. Journal of Agri. Science and Food Research, 9 (1), 1, 2018.

32. DONEEN L.D. Water quality for agriculture, vol 48, Department of Irrigation, University of California, Davis. 1964.

33. SELVAM S., MANIMARAN G., SIVASUBRAMANIAN P. Hydrochemical characteristics and GIS-based assessment of groundwater quality in the coastal aquifers of Tuticorin corporation, Tamilnadu, India, Appl. Water Sci., 3 (1), 145, 2013.

34. DAS S., NAG S. Deciphering groundwater quality for irrigation and domestic purposes - A case study in Suri
I and II blocks, Birbhum District, West Bengal, India. J. Earth Syst. Sci., 124 (5), 965, 2015.

35. KELLY W.P. Permissible composition and concentration of irrigated waters. In: Proceedings of the ASCE, 607, 1940.

36. JASROTIA A.S., TALOOR A.K., ANDOTRA U., KUMAR R. Monitoring and assessment of groundwater quality and its suitability for domestic and agricultural use in the Cenozoic rocks of Jammu Himalaya, India: A geospatial technology based approach. Groundwater Sustainable Development, 8 (2), 554, 2019.

37. ABDULLAH S., IQBAL M.S., ILYAS M., SHEJULE K.B., REHANA A. Groundwater pollution at Beed, Maharashtra as an effect of MSW Dumping. Bulletin of Environment, Pharmacology and Life Sciences, 1 (12), 43, 2012. 